Економічні науки: збірник наукових праць Луиького національного технічного університету. Серія "Регіональна економіка". Випуск 17 (67). Редкол.: відп. ред. к.е.н., професор І.В. Кривов'язюк. Луиьк: ІВВ Луцького НТУ, 2020. 348 с.

УДК 339.56

Вавдіюк Н. С., д.е.н., професор,

Корецька Н. І., к.е.н., доцент

Луцький національний технічний університет

\title{
РЕГІОНАЛЬНИЙ АНАЛІЗ МІЖНАРОДНОЇ ТОРГІВЛІ ТОВАРАМИ В УКРАЇНІ
}

У статті досліджено участь регіонів в загальній структурі зовнішньої торгівлі, Так, проаналізовано зміни обсягів зовнішньої торгівлі за регіонами України по експорту та імпорту товарів у період 2018-2019 років, представлено загальний обсяг сальдо зовнішньої торгівлі за регіонами України у 2019 році.

Ключові слова: регіон, зовнішньоекономічна діяльність, експорт товарів, імпорт товарів, сальдо.

Vavdiiuk N., Koretska N.

\section{REGIONAL ANALYSIS INTERNATIONAL TRADE IN GOODS IN UKRAINE}

Criteria for sustainable development of regions are largely determined by the efficiency of their foreign economic activity, which is an integral part of the functioning of 
Економічні науки: збірник наукових праць Луиького національного технічного університету. Серія "Регіональна економіка". Випуск 17 (67). Редкол.: відп. ред. к.е.н., професор І.В. Кривов’язюк. Луцьк: ІВВ Луцького НТУ, 2020. 348 с.

economic entities, regions and the country as a whole. It is established that Ukraine's foreign trade partners are different countries and territories of the world. Thus, the main trading partners in 2019 were the EU, China, the Russian Federation and Turkey. In total, 38 trading partners, which were most supplied with Ukrainian goods and services in the structure of exports of goods and services in 2019, accounted for $77 \%$. The largest share in exports of goods were vegetable products, mineral products, fats and oils of animal or vegetable origin, ready-made food products. In terms of imports, Ukraine imported the most goods and raw materials from China and purchased oil and gas from the Russian Federation. Exports of goods in 2019 continued to grow and compared to 2018 increased by $5.7 \%$. An increase in this indicator was observed in 17 regions of Ukraine, except for Luhansk, Odesa, Zakarpattia, Zaporizhia, Donetsk, Ternopil, Volyn and Kherson regions. The largest growth was characterized by Kyiv, Kirovohrad and Lviv regions. The volume of imports of goods in 2019 compared to 2018 in Ukraine increased by 6.3\%. The increase in this indicator was characterized by 16 regions of Ukraine (except for Chernihiv, Zaporizhia, Luhansk, Sumy, Kirovohrad, Zakarpattia, Donetsk and Ivano-Frankivsk regions). The largest growth occurred in Chernivtsi, Mykolaiv, Rivne, Khmelnytsky and Kherson regions. In general, the analysis showed that the regions of Ukraine, both in terms of imports and exports, are characterized by uneven distribution and their import dependence. Although the regions of Ukraine in recent years have a tendency to increase exports and imports of goods, but the problem of regional imbalances in international trade remains relevant. This situation requires improving the mechanism of redistribution of resources within the country, creating conditions and a positive image of regions to attract foreign investment resources, which, in turn, will increase the level of technological equipment, reduce interregional disparities and solve the problem of foreign trade.

Key words: region, foreign economic activity, export of goods, import of goods, balance.

Вавдиюк Н., Корецкая Н. РЕГИОНАЛЬНЫЙ АНАЛИЗ
МЕЖДУНАРОДНОЙ ТОРГОВЛИ ТОВАРАМИ В УКРАИНЕ

В статье исследовано участие регионов в общей структуре внешней торговли, проанализированы изменения объемов внешней торговли за регионами Украины по экспорту и импорту товаров в период 2018-2019 годов, представлен общий объем сальдо внешней торговли за регионами Украины в 2019 году.

Ключевые слова: регион, внешнеэкономическая деятельность, экспорт товаров, импорт товаров, сальдо.

Постанова проблеми у загальному вигляді та її зв'язок 3 важливими науковими і практичними завданнями. Україна - це сукупність регіонів, що відрізняються один від одного рівнем економічного розвитку, видами економічної діяльності, природно- 
Економічні науки: збірник наукових праць Луиького національного технічного університету. Серія "Регіональна економіка". Випуск 17 (67). Редкол.: відп. ред. к.е.н., професор І.В. Кривов'язюк. Луиьк: ІВВ Луцького НТУ, 2020. 348 с.

кліматичними умовами тощо. Регіони тісно взаємодіють між собою, формуючи єдиний економічний простір.

Критерії сталого розвитку регіонів багато в чому визначаються ефективністю їх зовнішньоекономічної діяльності, що $€$ невід'ємним елементом функціонування суб'єктів господарювання, регіонів та країни в цілому, сприяє підвищенню їх інвестиційного клімату, збільшує бюджетні надходження, забезпечує зайнятись населення тощо.

Ефективність економічного розвитку регіонів визначається товарними групами, сформованими за інтересами зовнішньоекономічного партнерства. Проте, події масштабного характеру, пов'язані з військовими конфліктами, соціальні бар'єри, цінові маніпуляції на різних ринках тощо є тими перешкодами, що гальмують зовнішньоекономічний розвиток територій України. I перед країною постають завдання: відновлення та розвитку експортного потенціалу країни, підвищення конкурентоспроможності вітчизняних товарів на світовому ринку, забезпечення раціональної структури експорту та імпорту, залучення іноземних інвестицій на взаємовигідних умовах.

Аналіз останніх досліджень, у яких започатковано вирішення проблеми. Проблеми зовнішньоекономічної діяльності України та їі регіонів досліджували зарубіжні та вітчизняні вчені О. Амоша, Б. Буркинський, М. Бутко, В. Геєць, Б. Данилишин, М. Долішній, В. Захарченко, І. Гукалова, С. Маруняк, В. Нагірна, Г. Підгрушний та інші, а аспекти зовнішньої торгівлі - Ю. Козак, О. Кузьміна, А. Мазаракі, Ю. Макогон, Т. Мельник, А. Філіпенко та ін. Проте, дослідження регіональних аспектів зовнішньої торгівлі України, встановлення географічної структури експорту залишається актуальною проблемою

Цілі статті: аналіз зовнішньоекономічної діяльності регіонів України; дослідження географічної структури експорту та імпорту товарів.

Викладення основного матеріалу дослідження 3 повним обгрунтуванням отриманих наукових результатів. Загалом специфіка зовнішньої торгівлі України полягає не лише у територіальних особливостях обсягів експорту та імпорту, а й у 
Економічні науки: збірник наукових праць Луиького національного технічного університету. Серія "Регіональна економіка". Випуск 17 (67). Редкол.: відп. ред. к.е.н., професор І.В. Кривов’язюк. Луцьк: ІВВ Луцького НТУ, 2020. 348 с.

відмінностях географічної структури зовнішньоторговельних операцій регіонів [1, с. 92].

Нині зовнішньоторговельними партнерами України є різні країни і території світу. Так, у I півріччі 2020 року експорт здійснювався до 220 країн, в тому числі: експорт як товарів, так і послуг - до 183 країн; експорт товарів - до 187 країн; експорт послуг - до 20 країн [2].

У 2019 році основними партнерами в експорті товарів були 38 країн, 3 яких 28 - країни СС (рис. 1).

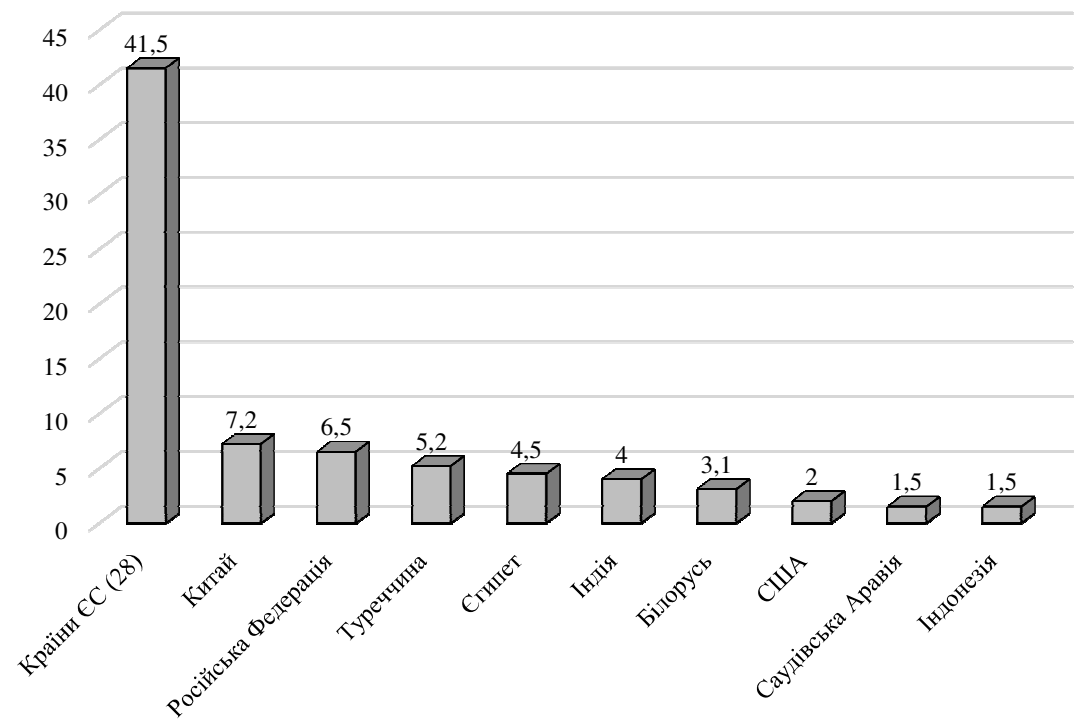

Рис. 1. Основні торговельні партнери України в експорті товарів у 2019 році, \%

Джерело: Держкомстат України

Отже, основними торгівельними партнерами у 2019 році (як і в інші роки) були країни СС 3 41,5\% у зовнішньоторговельному обороті товарів і послуг України. Крім того, значну частку займали Китай, Російська Федерація та Туреччина $(7,2 \% ; 6,5 \%$ та 5,2\% відповідно). В цілому 38 торговельних країн-партнерів, в які 
Економічні науки: збірник наукових праџь Луцького національного технічного університету. Серія "Регіональна економіка". Випуск 17 (67). Редкол.: відп. ред. к.е.н., професор І.В. Кривов’язюк. Луцьк: ІВВ Луцького НТУ, 2020. 348 с.

найбільше постачалися українські товари та послуги, в структурі експорту товарів і послуг у 2019 році складали 77\%.

Найбільшу частку в експорті товарів становили продукти рослинного походження, мінеральні продукти, жири та олії тваринного або рослинного походження, готові харчові продукти. Щодо імпорту, то найбільше Україна завозила товарів та сировини 3 Китаю та закуповувала нафту і газ в Російській Федерації.

Для аналізу зовнішньоекономічної діяльності в регіонах на рисунку 2 представлено сальдо зовнішньої торгівлі товарами в 2019 році.

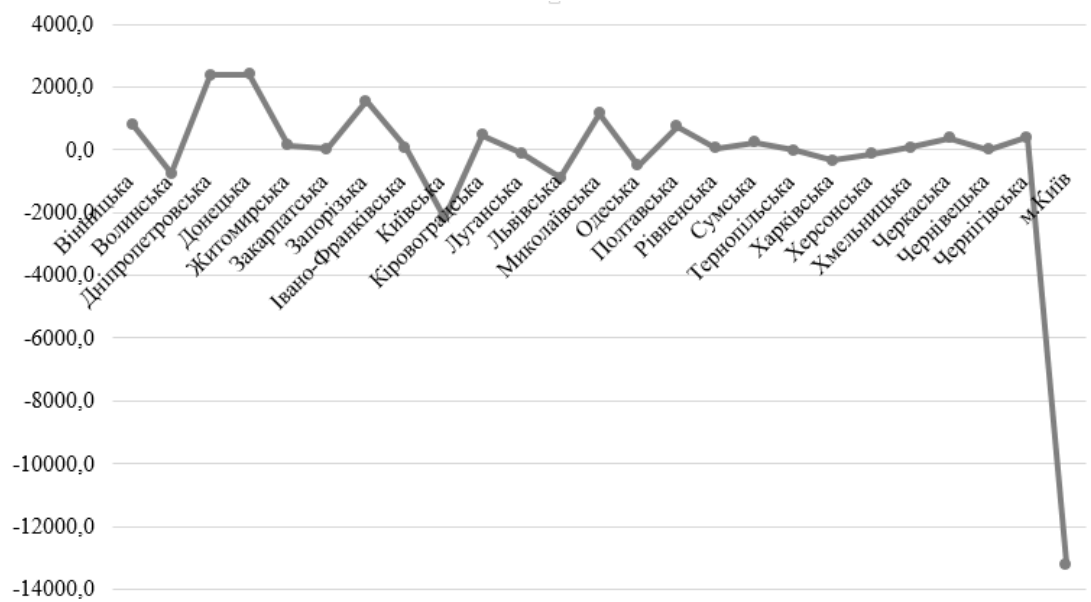

Рис. 2. Сальдо зовнішньої торгівлі товарами за регіонами України в 2019 р.

Джерело: власні узагальнення автора за даними: [3]

Із даних рисунка 2 бачимо, що найбільше позитивне сальдо спостерігалося в Донецькій та Дніпропетровській областях (2407,1 i 2385,0 млн. дол. США відповідно) у зв'язку зі значною кількістю на їх території експортоорієнтованих суб'єктів господарювання та високим рівнем виробничого потенціалу цих регіонів.

Негативним сальдо зовнішньої торгівлі товарами характеризувалися Київська (-2163,9 млн. дол. США), Львівська 
Економічні науки: збірник наукових праць Луиького національного технічного університету. Серія "Регіональна економіка". Випуск 17 (67). Редкол.: відп. ред. к.е.н., професор І.В. Кривов’язюк. Луцьк: ІВВ Луцького НТУ, 2020. 348 с.

(-885,7 млн. дол. США), Одеська (-497 млн. дол. США), Харківська (-330,7 млн. дол. США), Херсонська (-139 млн. дол. США), Луганська (-100,1 млн. дол. США) та Тернопільська (-15,8 млн. дол. США) області. Але найбільше негативно сальдо мало м. Київ 13,199 млрд. дол. США. В цілому таку негативну ситуацію можна пояснити значною чисельністю населення на їх площі та майже відсутністю внутрішнього виробництва.

Дослідимо динаміку зміни обсягу експорту-імпорту товарів за регіонами України (табл. 1, 2).

\section{Таблиця 1}

Аналіз обсягів експорту товарів за регіонами України у 2018-2019 роках

\begin{tabular}{|c|c|c|c|c|c|c|}
\hline \multirow[b]{3}{*}{ Регіони } & \multicolumn{6}{|c|}{ Експорт } \\
\hline & \multicolumn{3}{|c|}{$2018 \mathrm{p}$. } & \multicolumn{3}{|c|}{2019 p. } \\
\hline & $\begin{array}{c}\text { тис. дол. } \\
\text { США }\end{array}$ & $\begin{array}{c}\text { у\% } \\
\text { до } \\
2017 \\
\text { p. }\end{array}$ & $\begin{array}{c}\text { у\% до } \\
\text { загаль- } \\
\text { ного } \\
\text { обсягу }\end{array}$ & $\begin{array}{c}\text { тис. дол. } \\
\text { США }\end{array}$ & $\begin{array}{l}\text { у\% до } \\
2018 \text { p. }\end{array}$ & $\begin{array}{c}\text { у \% до } \\
\text { загальног } \\
\text { о обсягу }\end{array}$ \\
\hline 1 & 2 & 3 & 4 & 5 & 6 & 7 \\
\hline Україна, у т. ч.: & 47334987,0 & 109,4 & 100,0 & 50054605,8 & 105,7 & 100,0 \\
\hline Вінницька & 1429320,3 & 117,4 & 3,0 & 1455291,3 & 101,8 & 2,9 \\
\hline Волинська & 719980,9 & 104,5 & 1,5 & 694002,3 & 96,4 & 1,4 \\
\hline Дніпропетровська & 7722596,4 & 109,5 & 16,3 & 7907150,3 & 102,4 & 15,8 \\
\hline Донецька & 4845441,4 & 109,3 & 10,2 & 4631582,6 & 95,6 & 9,3 \\
\hline Житомирська & 661860,8 & 112,2 & 1,4 & 719034,6 & 108,6 & 1,4 \\
\hline Закарпатська & 1658975,7 & 114,7 & 3,5 & 1489957,9 & 89,8 & 3,0 \\
\hline Запорізька & 3377247,5 & 113,3 & 7,1 & 3080637,8 & 91,2 & 6,2 \\
\hline Івано-Франківська & 871353,5 & 131,0 & 1,8 & 911442,7 & 104,6 & 1,8 \\
\hline Київська & 1856333,0 & 106,2 & 3,9 & 1948367,6 & 105,0 & 3,9 \\
\hline Кіровоградська & 521761,0 & 125,5 & 1,1 & 707025,4 & 135,5 & 1,4 \\
\hline Луганська & 202920,8 & 86,8 & 0,4 & 152851,1 & 75,3 & 0,3 \\
\hline Львівська & 1895635,5 & 119,6 & 4,0 & 2202053,5 & 116,2 & 4,4 \\
\hline Миколаївська & 2112586,3 & 111,2 & 4,5 & 2152519,2 & 101,9 & 4,3 \\
\hline Одеська & 1668313,7 & 92,0 & 3,5 & 1384102,9 & 83,0 & 2,8 \\
\hline Полтавська & 1905900,9 & 102,2 & 4,0 & 2102409,2 & 110,3 & 4,2 \\
\hline Рівненська & 410890,2 & 107,2 & 0,9 & 440168,9 & 107,1 & 0,9 \\
\hline Сумська & 802120,7 & 119,2 & 1,7 & 883366,5 & 110,1 & 1,8 \\
\hline Тернопільська & 452483,7 & 119,0 & 1,0 & 434264,4 & 96,0 & 0,9 \\
\hline Харківська & 1278984,9 & 107,3 & 2,7 & 1415060,5 & 110,6 & 2,8 \\
\hline Херсонська & 269932,7 & 93,4 & 0,6 & 268128,7 & 99,3 & 0,5 \\
\hline Хмельницька & 638152,0 & 136,5 & 1,3 & 642345,9 & 100,7 & 1,3 \\
\hline Черкаська & 785641,5 & 127,2 & 1,7 & 863521,7 & 109,9 & 1,7 \\
\hline
\end{tabular}


Економічні науки: збірник наукових праиь Луиького національного технічного університету. Серія "Регіональна економіка". Випуск 17 (67). Редкол.: відп. ред. к.е.н., професор І.В. Кривов’язюк. Луцьк: ІВВ Луцького НТУ, 2020. 348 с.

Продовження таблиці 1

\begin{tabular}{|l|c|c|c|c|c|c|}
\multicolumn{1}{|c|}{1} & 2 & 3 & 4 & 5 & 6 & 7 \\
\hline Чернівецька & 200132,6 & 133,6 & 0,4 & 213837,3 & 106,9 & 0,4 \\
\hline Чернігівська & 754951,9 & 120,8 & 1,6 & 807323,7 & 106,9 & 1,6 \\
\hline м. Київ & 10248192,3 & 105,2 & 21,7 & 12491400,9 & 121,9 & 25,0 \\
\hline
\end{tabular}

Примітка:

1. Без урахування тимчасово окупованої території АР Крим, м. Севастополя та частини тимчасово окупованих територій у Донецькій та Луганській областях.

2. 3 урахуванням нерозподілених за регіонами поставок газу природного.

Як бачимо, недивлячись на погіршення цінової кон'юнктури на світових товарних ринках (чорні метали, пшениця, добрива), експорт товарів у 2019 році продовжував зростати. Так, у 2019 році у порівнянні з 2018 роком зростання експорту товарів в цілому по Україні склало 2,72 млрд. дол. США (5,7\%). Загалом підприємствами України було експортовано товарів на суму 50054,6 млн. дол. США.

Збільшення цього показника спостерігалося у 17 регіонах України, крім Луганської, Одеської, Закарпатської, Запорізької, Донецької, Тернопільської, Волинської та Херсонської областей (зменшення відповідно на 24,7\%; 17\%; 10,2\%; 8,8\%; 4,4\%; 4,0\%; $3,6 \% ; 0,7 \%)$. Найбільше зростання відбулося в таких регіонах: Кіровоградська (на 35,5\%), м. Київ (на 21,9\%) і Львівська (на 16,2\%).

Таблиця 2

Аналіз обсягів імпорту товарів за регіонами України у 2018-2019 роках

\begin{tabular}{|c|c|c|c|c|c|c|}
\hline \multirow[b]{3}{*}{ Регіони } & \multicolumn{6}{|c|}{ Імпорт } \\
\hline & \multicolumn{3}{|c|}{$2018 \mathrm{p}$. } & \multicolumn{3}{|c|}{2019 p. } \\
\hline & $\begin{array}{c}\text { тис. дол. } \\
\text { США }\end{array}$ & $\begin{array}{c}\mathrm{y} \% \\
\text { до } \\
2017 \\
\text { p. }\end{array}$ & $\begin{array}{c}\text { у\% до } \\
\text { загальног } \\
\text { о обсягу }\end{array}$ & $\begin{array}{c}\text { тис. дол. } \\
\text { США }\end{array}$ & $\begin{array}{c}\mathrm{y} \% \\
\text { до } \\
2018 \\
\text { p. }\end{array}$ & $\begin{array}{c}\text { у \% до } \\
\text { загального } \\
\text { обсягу }\end{array}$ \\
\hline 1 & 2 & 3 & 4 & 5 & 6 & 7 \\
\hline Україна, у т. ч.: & 57187578,0 & 115,3 & 100,0 & 60800173,12 & 106,3 & 100,0 \\
\hline Вінницька & 563048,7 & 138,3 & 1,0 & 631638,3 & 112,2 & 1,0 \\
\hline Волинська & 1368504,4 & 102,5 & 2,4 & 1455943,0 & 106,4 & 2,4 \\
\hline Дніпропетровська & 5264893,3 & 114,2 & 9,2 & 5522187,7 & 104,9 & 9,1 \\
\hline Донецька & 2247213,8 & 110,5 & 3,9 & 2224441,9 & 99,0 & 3,7 \\
\hline Житомирська & 531984,2 & 118,2 & 0,9 & 568590,4 & 106,9 & 0,9 \\
\hline Закарпатська & 1515819,8 & 113,0 & 2,7 & 1471227,2 & 97,1 & 2,4 \\
\hline Запорізька & 1762838,2 & 132,7 & 3,1 & 1529754,4 & 86,8 & 2,5 \\
\hline Івано-Франківська & 833540,8 & 130,8 & 1,5 & 831778,5 & 99,8 & 1,4 \\
\hline
\end{tabular}


Економічні науки: збірник наукових праиь Луиького національного технічного університету. Серія "Регіональна економіка". Випуск 17 (67). Редкол.: відп. ред. к.е.н., професор І.В. Кривов’язюк. Луцьк: ІВВ Луцького НТУ, 2020. 348 с.

Продовження таблиці 2

\begin{tabular}{|l|c|c|c|c|c|c|}
\hline \multicolumn{1}{|c|}{1} & 2 & 3 & 4 & 5 & 6 & 7 \\
\hline Київська & 3642341,6 & 107,0 & 6,4 & 4112295,7 & 112,9 & 6,8 \\
\hline Кіровоградська & 263055,7 & 111,4 & 0,5 & 250126,2 & 95,1 & 0,4 \\
\hline Луганська & 285036,0 & 104,4 & 0,5 & 252961,3 & 88,8 & 0,4 \\
\hline Львівська & 2707300,7 & 124,2 & 4,7 & 3087739,0 & 114,1 & 5,1 \\
\hline Миколаївська & 740041,3 & 94,7 & 1,3 & 988468,5 & 133,6 & 1,6 \\
\hline Одеська & 1546963,6 & 108,3 & 2,7 & 1881084,2 & 121,6 & 3,1 \\
\hline Полтавська & 1359553,2 & 118,3 & 2,4 & 1360177,2 & 100,1 & 2,2 \\
\hline Рівненська & 298790,4 & 87,6 & 0,5 & 382551,2 & 128,0 & 0,6 \\
\hline Сумська & 723283,0 & 131,2 & 1,3 & 656521,1 & 90,8 & 1,1 \\
\hline Тернопільська & 419019,5 & 119,1 & 0,7 & 450079,8 & 107,4 & 0,7 \\
\hline Харківська & 1738890,7 & 107,4 & 3,0 & 1745800,6 & 100,4 & 2,9 \\
\hline Херсонська & 327736,7 & 162,7 & 0,6 & 407103,5 & 124,2 & 0,7 \\
\hline Хмельницька & 446557,1 & 107,8 & 0,8 & 563970,4 & 126,3 & 0,9 \\
\hline Черкаська & 398120,2 & 98,7 & 0,7 & 477387,1 & 119,9 & 0,8 \\
\hline Чернівецька & 139620,2 & 123,3 & 0,2 & 208610,0 & 149,4 & 0,3 \\
\hline Чернігівська & 483320,3 & 108,6 & 0,8 & 419383,5 & 86,8 & 0,7 \\
\hline м. Київ & 23536557,9 & 118,6 & 41,2 & 25690337,3 & 109,2 & 42,3 \\
\hline
\end{tabular}

\section{Примітка:}

1. Без урахування тимчасово окупованої території АР Крим, м. Севастополя та частини тимчасово окупованих територій у Донецькій та Луганській областях.

2. 3 урахуванням нерозподілених за регіонами поставок газу природного.

Обсяг імпорту товарів у 2019 році в середньому по Україні зріс у порівнянні з 2018 роком на 3612,6 млн. дол. США, тобто на $6,3 \%$. Збільшення даного показника спостерігалося у 16 регіонах України, крім Чернігівської та Запорізької (зменшення на 13,2\%), Луганської (зменшення на 11,3\%), Сумської (зменшення на 9,2\%), Кіровоградської (зменшення на 4,9\%), Закарпатської (зменшення на 2,9\%), Донецької (зменшення на 1,0\%), Івано-Франківської (зменшення на $0,2 \%$ ) областей. Найбільше зростання відбулося у Чернівецькій (на 49,4\%), Миколаївській (на 33,6\%), Рівненській (на $28 \%$ ), Хмельницькій (на 26,3\%) і Херсонській (на 24,2\%) областях.

Варто зазначити, що лідером як за експортом, так і за імпортом товарів було м. Київ, чому сприяли кількість підприємств (в т. ч. і промислових), значний відсоток чисельності населення та наявність великих різних торгових площ.

Загалом аналіз засвідчив, що регіони України як за імпортом, так і за експортом характеризуються нерівномірністю розподілу та їх імпортозалежністю. Тобто Україна в цілому та ії області 
Економічні науки: збірник наукових праць Луиького національного технічного університету. Серія "Регіональна економіка". Випуск 17 (67). Редкол.: відп. ред. к.е.н., професор І.В. Кривов’язюк. Луцьк: ІВВ Луцького НТУ, 2020. 348 с.

зокрема не в змозі у повній мірі забезпечити внутрішнє споживання власним виробництвом та потребують додаткового імпорту товарів.

Висновки. Таким чином, хоча для регіонів України у період останніх років характерна тенденція до зростання експорту та імпорту товарів, проте проблема регіонального дисбалансу міжнародної торгівлі залишається актуальною. Така ситуація вимагає удосконалення механізму перерозподілу ресурсів всередині країни, створення умов та позитивного іміджу регіонів задля залучення зовнішніх інвестиційних ресурсів, що, в свою чергу, дозволить підвищити рівень технологічної оснащеності виробництва, зменшить міжрегіональну диспропорцію та вирішить проблему в зовнішній торгівлі.

\section{Список бібліографічного опису}

1.Кулєшова, Г. О., Кафтанова, П. О., Ключко, Л. В. Регіональні особливості експорту товарів України. Вісник Харківського національного університету. №40(1098). 2014. С. 92-96.

2.Загальні підсумки I півріччя 2020 року. Міністерство розвитку економіки, торгівлі та сільського господарства України. UTL: file://C:/Users/User/Downloads/ 3\%D0\%95\%D0\%BA\%D1\%81\%D0\%BF\%D0\%BE\%D1\%80\%D1\%82_\%D0\%A2\%D 0\%9F(06-2020).pdf

3.Державна служба статистики України. URL: http://www.ukrstat.gov.ua/

\section{References}

1.Kuljeshova, Gh. O., Kaftanova, P. O., Kljuchko, L. V. Reghionaljni osoblyvosti eksportu tovariv Ukrajiny. Visnyk Kharkivsjkogho nacionaljnogho universytetu. \#40(1098). 2014. S. 92-96.

2.Zaghaljni pidsumky I pivrichchja 2020 roku. Ministerstvo rozvytku ekonomiky, torghivli ta siljsjkogho ghospodarstva Ukrajiny. UTL: file:///C:/Users/User/Downloads/ 3\%D0\%95\%D0\%BA\%D1\%81\%D0\%BF\%D0\%BE\%D1\%80\%D1\%82_\%D0\%A2\%D0 $\% 9 \mathrm{~F}(06-2020)$.pdf

3.Derzhavna sluzhba statystyky Ukrajiny. URL: http://www.ukrstat.gov.ua/ 